\title{
Necessity of External Quality Control for anti-Mycoplasma pneumoniae IgM antibodies
}

\author{
Massimo De Paschale, Luisa Belvisi, Debora Cagnin, Teresa Cerulli, Maria Teresa Manco, \\ Laura Marinoni, Alessia Paganini, Pierangelo Clerici \\ U.O. Microbiologia, A.O. Ospedale Civile di Legnano (MI)
}

\section{Necessity of External Quality Control for anti-Mycoplasma pneumoniae IgM antibodies}

Key words: External quality control, IgM anti-Mycoplasma

\section{SUMMARY}

We evaluated the correlation among four commercial ELISA tests for the presence of anti-Mycoplasma pneumoniae IgM antibodies in 36 samples obtained from patients with respiratory infections. The overall concordance among the four tests was $30 \%$, while the one among single tests varies from $39 \%$ to $75 \%$. Given the variability of the results, it is necessary to implement a External Quality Control specific for anti-Mycoplasma pneumoniae IgM antibodies.

\section{INTRODUZIONE}

Il Mycoplasma pneumoniae è un microrganismo responsabile del $15-20 \%$ delle polmoniti che insorgono in comunità soprattutto tra $\mathrm{i}$ bambini $\mathrm{e}$ i giovani adulti oltre che di una serie di infezioni respiratorie di varia entità tra $i$ bambini più piccoli (5). La diagnosi si basa, tra l'altro, sui test di laboratorio che comprendono esami colturali e sierologici. L'isolamento in coltura, sebbene abbia il $100 \%$ di specificità, è relativamente meno sensibile rispetto ai test sierologici (7) ed ha lo svantaggio di essere lungo, potendo comportare tempi d'attesa fino a 5 settimane. La fissazione del complemento è stato per un lungo periodo il test sierologico più usato, ma, oltre ad avere una bassa sensibilità, soprattutto se i campioni non sono stati prelevati nei tempi corretti, può dare reazioni aspecifiche $(7,8)$. Anche in questo caso i tempi di risposta sono lunghi, dal momento che il secondo campione deve essere raccolto di norma dopo due-tre settimane dal primo. Per poter arrivare a formulare una diagnosi in tempi più stretti sono state messe a punto tecniche di biologia molecolare per la ricerca diretta del Mycoplasma pneumoniae $(1,3)$ e test ELISA o in immunofluorescenza per la ricerca delle IgG e IgM specifiche $(10,14,15)$. Le IgM compaiono circa 7-10 giorni dopo l'infezione e precedono di circa 2 settimane le IgG. La loro presenza è, quindi, indicativa di un'infezione acuta o recente $(7,11)$. In alcuni casi, però, le IgM possono persistere nell'individuo adulto fino ad un anno dopo l'infezione, oppure possono non essere rilevabili, soprattutto in caso di reinfezione $(4,7,12,14)$. Nonostante questi limiti, sono stati formulati e commercializzati test immunoenzimatici per la ricerca di IgM specifiche con indubbi vantaggi di ordine pratico sia dal punto di vista esecutivo che dei tempi di risposta. La formulazione del kit e il tipo di antigene utilizzato per il coating delle piastre, comporta, però, una notevole variabilità nei risultati qualora gli stessi campioni sono esaminati con kit diversi (9). Studi di valutazione su kit commerciali hanno, infatti, riportato valori di sensibilità che variano dal $35 \%$ all' $89 \%$ e valori di specificità dal $25 \%$ al $100 \%$ a seconda dei test usati e delle casistiche in studio con valori predittivi positivi e negativi che variano rispettivamente dal $31 \%$ al $100 \%$ e dall' $83 \%$ al $94 \%(2,9,13)$.

Scopo del nostro lavoro è stato quello di valutare la concordanza tra quattro test ELISA commerciali per la ricerca di anticorpi IgM antiMycoplasma pneumoniae in campioni di soggetti con infezioni respiratorie pervenuti all'U.O. di Microbiologia dell'Ospedale di Legnano.

\section{MATERIALI E METODI}

Sono stati selezionati 36 campioni provenienti da altrettanti pazienti (17 maschi e 19 femmine; età: 
4-93 anni) con infezioni respiratorie che, in base al test di screening in uso (determinato in doppio) sono stati suddivisi in tre gruppi:

Gruppo I: 6 negativi

Gruppo II: 13 border line

Gruppo III: 17 positivi

Nel gruppo I nessuno dei pazienti aveva una clinica compatibile con infezione da Mycoplasma. Nel gruppo II in 12 pazienti la clinica non era compatibile con un'infezione da Mycoplasma, mentre in uno la diagnosi era incerta. Nel gruppo III in 9 pazienti la clinica era compatibile con un'infezione da Mycoplasma, in 3 non compatibile e in 5 la diagnosi era incerta.

Il test in uso (Test A) utilizza come antigene adeso sulla fase solida un preparato contenente la proteina di membrana P1 (Sero MP ${ }^{\mathrm{TM}}$ IgM, Savyon Diagnostics, Ashodod, Israel).

I 36 campioni sono stati esaminati in doppio con i seguenti Kit:

Test B: Serion classic Mycoplasma pneumoniae IgM (Virion/Serion, Würzburg, Germany)

Test C: Mycoplasma pneumoniae IgM-ELISA (NovaTec Immunodiagnostica, Dietzenbach,
Germany)

Test D: SeroMP ${ }^{\mathrm{TM}}$ Recombinant IgM (Savyon Diagnostics Ltd, Ashodod, Israel)

I Test $\mathrm{B}$ e $\mathrm{C}$ utilizzano antigeni nativi contenenti la proteina di membrana $\mathrm{P} 1$, mentre il test $\mathrm{D}$ contiene oltre ad una frazione purificata di proteine di membrana anche antigeni ricombinanti.

Nessuno dei campioni in studio era positivo per Fattore Reumatoide (Arthri-Slidex, bioMérieux, Marcy l'Etoile, France).

\section{RISULTATI}

Nel gruppo I i campioni sono risultati negativi con tutti i test, mentre vi sono discordanze nei gruppi II e III (tabella 1).

I risultati totali per ogni test sono riportati in tabella 2.

La concordanza globale tra tutti i quattro test è stata del 30\% (12/36). Le concordanze singole tra i vari test variano dal $39 \%$ al $75 \%$ (tabella 3 ).

In base alla compatibilità clinica i risultati della ricerca degli anticorpi anti-Mycoplasma IgM con i quattro test ELISA sono riportati in tabella 4.

Tabella I. Risultati per la ricerca di anticorpi IgM anti-Mycoplasma pneumoniae con tre differenti test ELISA in tre gruppi di campioni selezionati con test di screening

\begin{tabular}{cccc}
\hline RISULTATO & ANTI-MYCOPLASMA IgM \\
\hline & TEST B & TEST C & TEST D \\
\hline NEGATIVO & GRUPPO I (NEGATIVI = 6) & $6(100 \%)$ \\
\hline NEGATIVO & $6(100 \%)$ & GRUPPO II (BORDER LINE = I 3) & $12(92 \%)$ \\
\hline BORDER LINE & $4(31 \%)$ & $13(100 \%)$ & $0(0 \%)$ \\
\hline POSITIVO & $2(15 \%)$ & $0(0 \%)$ & $1(8 \%)$ \\
\hline NEGATIVO & $7(54 \%)$ & $0(0 \%)$ & $3(18 \%)$ \\
\hline BORDER LINE & I (6\%) & $6(35 \%)$ & $4(23 \%)$ \\
\hline POSITIVO & $2(12 \%)$ & $3(18 \%)$ & $10(59 \%)$ \\
\hline
\end{tabular}

Tabella 2. Risultati globali per ricerca anticorpi IgM anti-Mycoplasma pneumoniae con quattro differenti test ELISA

\begin{tabular}{ccccc}
\hline RISULTATO & \multicolumn{4}{c}{ ANTI-MYCOPLASMA IgM } \\
\hline & TEST A & TEST B & TEST C & TEST D \\
\hline NEGATIVO & $6(17 \%)$ & $11(31 \%)$ & $25(69 \%)$ & $21(58 \%)$ \\
\hline BORDER LINE & $13(36 \%)$ & $4(11 \%)$ & $3(8 \%)$ & $4(11 \%)$ \\
\hline POSITIVO & $17(47 \%)$ & $21(58 \%)$ & $8(22 \%)$ & $11(31 \%)$ \\
\hline TOTALE & 36 & 36 & 36 & 36 \\
\hline
\end{tabular}

Tabella 3. Concordanza tra quattro differenti test ELISA per la ricerca di anticorpi IgM anti-Mycoplasma pneumoniae

\begin{tabular}{cccc}
\hline TEST ELISA & & CONCORDANZA & TEST C \\
\hline TEST B & TEST A & TEST B & $18(50 \%)$ \\
\hline TEST C & $22(61 \%)$ & - & - \\
\hline TEST D & $14(39 \%)$ & $18(50 \%)$ & $27(75 \%)$ \\
\hline
\end{tabular}


Tabella 4. Confronto tra i risultati per la ricerca di anticorpi anti-Mycoplasma pneumoniae con quattro test ELISA e clinica compatibile, non compatibile o incerta per infezione da Mycoplasma

\begin{tabular}{|c|c|c|c|c|c|c|c|c|c|c|c|c|}
\hline \multirow[b]{3}{*}{ CLINICA } & \multicolumn{12}{|c|}{ ANTI-MYCOPLASMA IgM } \\
\hline & \multicolumn{3}{|c|}{ TEST A } & \multicolumn{3}{|c|}{ TEST B } & \multicolumn{3}{|c|}{ TEST C } & \multicolumn{3}{|c|}{ TEST D } \\
\hline & NEG & POS & $\begin{array}{l}\text { Border } \\
\text { Line }\end{array}$ & NEG & POS & $\begin{array}{l}\text { Border } \\
\text { Line }\end{array}$ & NEG & POS & $\begin{array}{l}\text { Border } \\
\text { Line }\end{array}$ & NEG & POS & $\begin{array}{l}\text { Border } \\
\text { Line }\end{array}$ \\
\hline Compatibile & $\begin{array}{l}0 \\
0 \%\end{array}$ & $\begin{array}{l}9 \\
100 \%\end{array}$ & $\begin{array}{l}0 \\
0 \%\end{array}$ & $\begin{array}{l}0 \\
0 \%\end{array}$ & $\begin{array}{l}8 \\
88.9 \%\end{array}$ & $\begin{array}{l}1 \\
11.1 \%\end{array}$ & $\begin{array}{l}0 \\
0 \%\end{array}$ & $\begin{array}{l}7 \\
77.8 \%\end{array}$ & $\begin{array}{l}2 \\
22.2 \%\end{array}$ & $\begin{array}{l}0 \\
0 \%\end{array}$ & $\begin{array}{l}9 \\
100 \%\end{array}$ & $\begin{array}{l}0 \\
0 \%\end{array}$ \\
\hline $\begin{array}{l}\text { Non } \\
\text { compatibile }\end{array}$ & $\begin{array}{l}6 \\
28.6 \%\end{array}$ & $\begin{array}{l}3 \\
14.3 \%\end{array}$ & $\begin{array}{l}12 \\
27.1 \%\end{array}$ & $\begin{array}{l}11 \\
52.4 \%\end{array}$ & $\begin{array}{l}7 \\
33.3 \%\end{array}$ & $\begin{array}{l}3 \\
14.3 \%\end{array}$ & $\begin{array}{l}21 \\
100 \%\end{array}$ & $\begin{array}{l}0 \\
0 \%\end{array}$ & $\begin{array}{l}0 \\
0 \%\end{array}$ & $\begin{array}{l}20 \\
95.2 \%\end{array}$ & $\begin{array}{l}0 \\
0 \%\end{array}$ & $\begin{array}{l} \\
4.8 \%\end{array}$ \\
\hline Incerta & $\begin{array}{l}0 \\
0 \%\end{array}$ & $\begin{array}{l}5 \\
83.3 \%\end{array}$ & $\begin{array}{l}1 \\
16.7 \%\end{array}$ & $\begin{array}{l}0 \\
0 \%\end{array}$ & $\begin{array}{l}6 \\
100 \%\end{array}$ & $\begin{array}{l}0 \\
0 \%\end{array}$ & $\begin{array}{l}4 \\
66.7 \%\end{array}$ & $\begin{array}{l}1 \\
16.7 \%\end{array}$ & $\begin{array}{l}1 \\
16.7 \%\end{array}$ & $\begin{array}{l}1 \\
16.7 \%\end{array}$ & $\begin{array}{l}2 \\
33.3 \%\end{array}$ & $\begin{array}{l}3 \\
50 \%\end{array}$ \\
\hline
\end{tabular}

\section{DISCUSSIONE}

La risposta immunitaria ad un'infezione da Mycoplasma pneumoniae è eterogenea e la cinetica anticorpale dipende dall'antigene che ha stimolato la risposta (6). Quindi è determinante la scelta e la processazione degli antigeni nella preparazione di test capaci di evidenziare le IgM specifiche. Sono stati messi a punto e commercializzati molti test ELISA che utilizzano preparati differenti per sensibilizzare la fase solida. L'ampia diffusione di questi test è dovuta alla possibilità di formulare una diagnosi in tempi veloci dal momento che è possibile utilizzare un singolo campione di siero.

Le performances dei vari test sono, però, differenti e i livelli di sensibilità e specificità, riportati in letteratura, variano molto tra $\mathrm{i}$ differenti test $(2,9,13)$. Nel nostro studio abbiamo voluto verificare la concordanza tra i singoli test in prova. Le concordanze variano tra il $39 \%$ e il $75 \%$ a seconda della coppia di test utilizzati e se si considerano tutti i quattro test insieme la concordanza scende al $30 \%$.

Tale discrepanza appare allarmante, soprattutto nell'ottica di poter fornire un ausilio diagnostico al clinico in caso di una clinica dubbia. Nei nostri casi, invece, la discordanza tra $i$ vari test ha aumentato l'incertezza. In conclusione appare quanto mai necessario implementare un Controllo di Qualità Esterno che sia in grado di valutare su vasta scala le performance dei vari test e di poter fornire informazioni utili sull'attendibilità delle risposte.

\section{BIBLIOGRAFIA}

1. Abele-Horn M, Busch U, Nitschko H, et al. Molecular approaches to diagnosis of pulmonary diseases due to Mycoplasma pneumoniae. J Clin Microbiol 1998; 36: 548-51.

2. Beersma MF, Dirven K, van Dam AP, et al. Evaluation of 12 commercial tests and the complement fixation test for Mycoplasma pneumoniae-specific immunoglobulin $\mathrm{G}$ (IgG) and IgM antibodies, with PCR used as the "gold standard". J Clin Microbiol 2005; 43: 2277-85.
3. Blackmore TK, Reznikov M, Gordon DL. Clinical utility of the polymerase chain reaction to diagnose Mycoplasma pneumoniae infection. Pathology 1995; 27: 177-81.

4. Chamberlain P, Saeed AA. A study of the specific IgM antibody response in Mycoplasma pneumoniae infection in man. J Hyg (Lond) 1983; 90: 207-11.

5. Foy HM, Kenny GE, McMahan, R, Mansy AM, Grayston JT. Mycoplasma pneumoniae pneumonia in an urban area. Five years of surveillance. JAMA 1970; 214: 1666-72.

6. Jacobs EA, Bennewitz A, Bredt W. Reaction pattern of human anti-Mycoplasma pneumoniae antibodies in enzyme-linked immunosorbent assays and immunoblotting. J Clin Microbiol 1986; 23: 517-22.

7. Jacobs E. Serological diagnosis of Mycoplasma pneumoniae infections: a critical review of current procedures. Clin infect Dis 1993; 17 (Suppl. 1): S79-S82.

8. Leinikki PO, Panzar P, Tykkä H. Immunoglobulin M antibody response against Mycoplasma pneumoniae lipid antigen in patients with acute pancreatitis. J Clin Microbiol 1978; 8: 113-8.

9. Petitjean J, Vabret A, Gouarin S, Freymuth F. Evaluation of four commercial immunoglobulin $G$ (IgG)- and IgM-specific enzyme immunoassay for diagnosis of Mycoplasma pneumoniae infections. J Clin Microbiol 2002; 40: 165-71.

10. Räisänen SM, Suni JI, Leinnikki P. Serological diagnosis of Mycoplasma pneumoniae infection by enzyme immunoassay. J Clin Pathol 1980; 33: 836-40.

11. Shearman MJ, Cubic HA, Inglis JM. Mycoplasma pneumoniae infection: early diagnosis by detection of specific IgM by immunofluorescence. Br J Biomed Sci 1993; 50: 305-8.

12. Sillis M. The limitations of IgM assays in the serological diagnosis of Mycoplasma pneumoniae infections. J Med Microbiol 1990; 33: 253-8.

13. Thacker WL, Talkington DF. Analysis of complement fixation and commercial enzyme immunoassay for detection of antibodies to Mycoplasma pneumoniae in human serum. Clin Diagn Lab Immunol 2000; 7: 778-80.

14. Uldum SA, Jensen JS, Søndergård-Andersen J, Lind K. Enzyme immunoassay for detection of immunoglobulin $\mathrm{M}(\mathrm{IgM})$ and IgG antibodies to Mycoplasma pneumoniae. J Clin Microbiol 1992; 30: 1198-204.

15. Van Griethuysen AJ, de Graaf R, van Druten JA, et al. Use of the enzyme-linked immunosorbent assay for the early diagnosis of Mycoplasma pneumoniae infection. Eur J Clin Microbiol 1984; 3: 116-21. 


\title{
In vitro synergism between rokitamycin and cotrimoxazole against $S$. aureus and coagulase-negative staphylococci (CoNS)
}

\author{
Simona Roveta',Anna Marchese', Eugenio A. Debbia', Roberto Bandettini \\ 'University of Genoa, Di.S.C.A.T.- Sezione di Microbiologia, Largo R. Benzi 10, I6I32 Genoa, Italy. \\ ${ }^{2}$ Istituto G. Gaslini, Largo G. Gaslini 5, I6/47 Genoa, Italy.
}

In vitro synergism between rokitamycin and cotrimoxazole against $S$. aureus and coagulasenegative staphylococci (CoNS)

Key words: Antibiotic synergism, Staphylococci, Macrolides, Cotrimoxazole

\section{SUMMARY}

Background. Synergism between cotrimoxazole (SXT) and rokitamycin (ROK) was previously described against $S$. pyogenes and $S$. pneumoniae. The aim of this study was to confirm this phenomenon in Staphylococcus isolates displaying different macrolide resistance phenotypes.

Methods. Synergism between SXT plus ROK against 162 staphylococci 75 S. aureus and 87 coagulase-negative staphylococci, CoNS) recently isolated was detected by a preliminary screening based on a qualitative method. Time-kill experiments were performed on representative strains adopting standard procedures.

Results. When SXT was combined with ROK, a synergistic reaction was observed against $36.8 \%$ and $56.8 \%$ of S. aureus and CoNS strains, respectively. Synergism was more widespread in methicillin-susceptible strains $(57.9 \%$ and $79.5 \%$ of S. aureus and CoNS, respectively) in comparison with methicillin-resistant strains ( $16.2 \%$ and $37.5 \%$ of S. aureus and CoNS, respectively). In none of the experiments antagonism was demonstrated. Results of timekill experiments confirmed those obtained with double-disk assay in all the strains.

Conclusion. Differences in macrolide-resistance phenotype and in cotrimoxazole resistance mechanism may only partially explain the heterogeneous results observed in this study. Differences in ribosomal structure and intracellular accumulation of the drugs among the various microrganisms may also contribute to determine the effects of this association of drugs.

\section{INTRODUCTION}

Macrolides inhibit protein synthesis in bacterial cell by binding to the $50 \mathrm{~S}$ ribosomial subunit, making specific interactions with the 23S RNA. The two most common mechanisms of resistance are modification of bacterial ribosome, resulting in reduced binding of the drug and efflux of the antibiotic molecules from bacterial cells. The change in ribosome structure is due to methylation of a nucleotide in 23S RNA mediated by an enzyme named Erm and confers high-level resistance to macrolides, lincosamides and streptogramin B (MLS $)$ classes. Erm-mediated resistance exists in two patterns: an inducible $\left(\mathrm{iMLS}_{\mathrm{B}}\right)$ and constitutive (cMLS $S_{\text {) }}$ one, the first developing only after macrolide administration, the second not requiring the presence of the drug.

Macrolides efflux-mediated resistance is due to the mef genes product in streptococci that confers resistance to 14 - and 15 - but not 16 -membered macrolides, lincosamides or streptogramin B. Even the $m r s$ genes found in staphylococci confer a macrolides efflux mediated, but differ from the mef group because they confer resistance to both macrolide and streptogramine B antibiotics $(1,6$, 8, 13-14).

Trimethoprim (TMP) is a synthetic drug commonly used in combination with sulfamethoxazole (SMX), a sulfonamide antibiotic. This combination, also known as co-trimoxazole (SXT), results in a synergistic antibacterial effect attributed to inhibition of folate biosynthesis pathway in two different points. Sulfamethoxazole blocks the enzyme dihydropteroate synthase (DHPS), while trimethoprim inhibits dihydrofolate reductase (DHFR) blocks the conversion of dihydrofolic acid to its functional form, tetrahydrofolic acid. Bacteria are unable to take up folic acid from the 
environment (i.e. the infection host) and are thus dependent on their own ex-novo synthesis. Folate pathway is essential to the synthesis of bacterial nucleic acids and protein production. Inhibition of this pathway affects protein biosynthesis through the deficiency of methionine, glycine and formyl group of tRNA and deprives bacteria of purines and thymine essentials for DNA replication and transcription. Co-trimoxazole resistance is due to mutations in the DHFR gene or duplications within the gene encoding for DHPS with production of drug resistant DHPS and DHFR $(10,19)$.

Synergistic activity of macrolides, when they were paired with SXT, was already noted in previous studies. The combination of roxithromycin and sulphamethoxazole was effective in the prevention of Toxoplasma gondii and Pneumocystis carinii infections (2). Activity of roxithromycin was improved by combination with sulphamethoxazole even against Haemophilus influenzae (7). Synergism or additive activity of combination macrolides-SXT were observed even in pathogens as Pseudomonas aeruginosa, Burkholderia cepacia, Stenotrophomonas maltophilia, and Alcaligenes xylosoxidans in which macrolide agents may reduce the virulence factors (16).

In vitro synergism between co-trimoxazole (SXT) and rokitamycin (ROK) against streptococci was described in a previously study (15). To investigate more deeply this phenomenon, a wide screening on staphylococcal solates was carried out and time-kill tests on representative strains displaying different macrolide resistance phenotypes, were performed.

\section{MATERIAL AND METHODS Microrganisms}

During the time period 2005-2006, 162 staphylococci (75 S. aureus 73 S. epidermidis, 11 S. haemolyticus and 3 S. hominis) derived from blood, respiratory tract, urine and skin samples were collected, from out- and inpatients, in the Clinical Microbiology Laboratory of the University of Genoa (Italy). Microrganisms were identified according to standard procedures (11) and staphylococci isolates characterized for their methicillin-susceptibility phenotype employing the disk diffusion method (3).

Macrolides resistance phenotype of each erythromycin-resistant strain was determined by double disk test with erythromycin $(15 \mu \mathrm{g})$ and clindamycin $(2 \mu \mathrm{g})$ as previously described $(5,18)$. The disks were placed $20 \mathrm{~mm}$ apart on MuellerHinton (MH) agar (Biolife, Milan, Italy) plate which was inoculated with the bacterial suspension (turbidity of $0.5 \mathrm{McFarland}$ ) and incubated for 18 hours at $35^{\circ} \mathrm{C}$. Constitutive resistance (cMLS в $_{\text {в }}$ notype) was indicated by the absence of a significant zone of inhibition around the two disks. Inducible resistance (iMLS ${ }_{\text {в }}$ phenotype), instead, was pointed out by the blunting of the clindamycin zone of inhibition proximal to the erythromycin disk. M phenotype was revealed by susceptibility to clindamycin without blunting of the zone of inhibition around the disk.

\section{Drugs}

Antibiotic powders of trimethoprim-sulfamethoxazole and rokitamycin were obtained from commercial sources (Roche S.p.A. and Prodotti Formenti S.r.l., Milan, Italy, respectively) and sterile stock solutions were prepared following the instructions of the manufacturers. Antibiotic disks of erythromycin, clindamycin, rokitamycin and cotrimoxazole were obtained from Oxoid S.pA. (Milan, Italy).

\section{Antimicrobial synergism}

A preliminary screening test to assess synergism between co-trimoxazole (SXT) and the 16-membered ring macrolides rokitamycin (ROK) was performed employing a qualitative method. The technique used the same standard inoculum (turbidity of 0.5 McFarland) and $\mathrm{MH}$ agar plates as the Kirby-Bauer susceptibility test. Disks containing the two drugs (SXT $25 \mu \mathrm{g}$ and ROK $30 \mu \mathrm{g}$ ) were placed $20 \mathrm{~mm}$ apart on MH agar plate which was inoculated with the bacterial suspension and incubated for 18 hours at $37^{\circ} \mathrm{C}$. The pattern observed with additive or indifferent combinations was composed by two independent circles. With synergistic combinations, instead, enhancement or bridging was observed near the junction of the two zones of inhibition (10).

Bactericidal activity of the combination SXT plus ROK was further assessed by employing the time-kill method on several strains, representative of each macrolides resistance phenotype. Time-kill studies were performed adopting standard procedures $(10,12)$ using flasks containing $10 \mathrm{~mL}$ of logphase bacterial cultures diluted to $10^{6}-10^{7}$ cells $/ \mathrm{mL}$ and previously grown at $37^{\circ} \mathrm{C}$ in $\mathrm{MH}$ broth medium. The drugs were added to bacterial cultures at concentrations corresponding to $0.5 \times$ MIC. Flasks with the antibiotics alone as well as drug-free flasks were included as controls and the cultures were incubated at $37^{\circ} \mathrm{C}$. Bacterial counts were carried out two times, just before the compounds were added (zero time) and at 2, 6 and $24 \mathrm{~h}$ by spreading aliquots of $0.1 \mathrm{~mL}$ of the suitable dilutions onto $\mathrm{MH}$ agar plates and incubating for $24 \mathrm{~h}$ at $37^{\circ} \mathrm{C}$. Colony counts were performed and killing curves were plotted using the mean colony counts at each time point.

\section{RESULTS}

When SXT was combined with ROK a synergistic reaction was observed against $36.8 \%$ of $S$. aureus and $56.8 \%$ of CoNS strains. In S. aureus, synergism 
was more widespread $(57.9 \%)$ in methicillin-susceptible (MET-S) than in methicillin-resistant (MET-R) strains (16.2\%). Similarly, in coagulasenegative staphylococci (CoNS) synergistic interaction was found in about $80 \%$ of the MET-S strains and in $37.5 \%$ of MET-R ones. In particular, synergism was not observed against staphylococci showing $\mathrm{CMLS}_{\text {в }}$ phenotype. None of the isolates presented macrolide efflux-resistance phenotype (table 1). In all the selected representative strains, time-kill values confirmed those observed during the preliminary screening assay. Employing SXT in combination with ROK, a reduction of $99 \%$ (or more) of $\mathrm{CFU} / \mathrm{ml}$ (in comparison to each single drug) was observed in all the isolates in which synergism was previously found. Absence of synergistic interaction was confirmed in those strains that in the preliminary screening test showed a typical pattern of indifferent combination. In none of the strains antagonism was demonstrated (table 2).

Table I. Interaction between cotrimoxazole and rokitamycin in Staphylococcus strains displaying different macrolide resistance phenotypes

\section{MICRORGANISM MACROLIDES}

(N. STRAINS )

S. aureus MET-R (37)

\begin{tabular}{cc}
\hline S. aureus MET-R (37) & S \\
\hline & iMLS \\
\hline & cMLS \\
\hline S. aureus MET-S (38) & TOT \\
\hline & S \\
\hline & iMLS \\
\hline CoNS MET-R (48) (1) & cMLS \\
\hline & TOT \\
\hline & S \\
\hline & iMLS \\
\hline CoNS MET-S (39) ${ }^{(2)}$ & cMLS \\
\hline & TOT \\
\hline & S \\
\hline & iMLS \\
\hline & cMLS \\
\hline & TOT
\end{tabular}

CoNS: coagulase negative staphylococci.

(I) 40 S. epidermidis, 6 S. haemolyticus and 2 S. homini

$S$

MLS
SYNERGISM INDIFFERENCE N. of strains (\%)

$6(50 \%) \quad 6(50 \%)$

$10(100 \%)$

0
$15(100 \%)$

6 (16.2\%)

3 I (83.8\%)

$20(62.5 \%)$

$12(37.5 \%)$

$2(100 \%)$

$4(100 \%)$

22 (57.9\%)

16 (42. I\%)

$2(50 \%)$

2 (50\%)

$16(66.7 \%)$

8 (33.3\%)

0

$20(100 \%)$

18 (37.5\%)

30 (62.5\%)

$20(76.9 \%)$

II (100\%)

$6(23.1 \%)$

0

2 (100\%)

3 I (79.5\%)

8 (20.5\%)

- (2) 33 S. epidermidis, 4 S. haemolyticus and 2 S. homini

Table 2. Time-kill assays of the combination cotrimoxazole plus rokitamycin in Staphylococcus strains displaying different macrolide resistance phenotypes

\begin{tabular}{|c|c|c|c|c|c|c|}
\hline \multirow[t]{2}{*}{ MICRORGANISM } & \multirow{2}{*}{$\begin{array}{l}\text { MACROLIDES } \\
\text { RESISTANCE } \\
\text { PHENOTYPE }\end{array}$} & \multirow[t]{2}{*}{$\begin{array}{l}\text { PRELIMINARY } \\
\text { SCREENING }\end{array}$} & \multirow{2}{*}{$\begin{array}{l}\text { STRAINS } \\
\text { TESTED } \\
\mathbf{N} . \\
\end{array}$} & \multicolumn{3}{|c|}{$\begin{array}{l}\% \text { OF CFU/ML } \\
\text { REDUCTION * }\end{array}$} \\
\hline & & & & $2 \mathrm{~h}$ & $6 \mathrm{~h}$ & $24 \mathrm{~h}$ \\
\hline \multirow[t]{4}{*}{ S. aureus MET-R } & S & Synergism & 3 & $<90$ & 90 & 99 \\
\hline & & Indifference & 3 & $<90$ & $<90$ & $<90$ \\
\hline & iMLS ${ }_{B}$ & Indifference & 3 & $<90$ & $<90$ & $<90$ \\
\hline & $\mathrm{CMLS}_{\mathrm{B}}$ & Indifference & 3 & $<90$ & $<90$ & $<90$ \\
\hline \multirow[t]{4}{*}{ S. aureus MET-S } & $S$ & Synergism & 3 & 90 & 90 & 99 \\
\hline & & Indifference & 3 & $<90$ & $<90$ & $<90$ \\
\hline & iMLS $_{\mathrm{B}}$ & Synergism & 2 & $<90$ & 90 & 99 \\
\hline & $\mathrm{CMLS}_{\mathrm{B}}$ & Indifference & 3 & $<90$ & $<90$ & $<90$ \\
\hline \multirow[t]{5}{*}{ S. epidermidis MET-R } & $S$ & Synergism & 2 & 90 & 90 & 99 \\
\hline & & Indifference & 2 & $<90$ & $<90$ & $<90$ \\
\hline & iMLS $_{B}$ & Synergism & 3 & $<90$ & 90 & 99 \\
\hline & & Indifference & 3 & $<90$ & $<90$ & $<90$ \\
\hline & $\mathrm{CMLS}_{\mathrm{B}}$ & Indifference & 3 & $<90$ & $<90$ & $<90$ \\
\hline \multirow[t]{4}{*}{ S. epidermidis MET-S } & $\mathrm{S}$ & Synergism & 3 & 90 & 90 & 99 \\
\hline & & Indifference & 3 & $<90$ & $<90$ & $<90$ \\
\hline & $\mathrm{iMLS}_{\mathrm{B}}$ & Synergism & 3 & $<90$ & 90 & 99 \\
\hline & $\mathrm{CMLS}_{\mathrm{B}}$ & Indifference & 2 & $<90$ & $<90$ & $<90$ \\
\hline
\end{tabular}

*mean of the results obtained from tested strains. 


\section{DISCUSSION}

All macrolide-resistant staphylococci assayed in this study showed either an inducible or a constitutive $\mathrm{MLS}_{\mathrm{в}}$ phenotype. As reported in Literature, the resistance-phenotype (due to the presence of different evolutionary variants of the erm determinant) is the most widespread pattern of resistance $(4,8-9,17)$. The constitutive phenotype generally showed absence of synergism, while the inducible resistance one led to a more heterogeneous pattern (synergism or indifference).

The multiplicity of resistance mechanisms to macrolides results in a variety of phenotypic expressions of resistance: $\mathrm{cMLS}_{\mathrm{B}}$ type isolates show generally high-level of resistance to 16

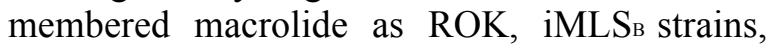
instead, present a wide range of susceptibility to non inducers macrolides, correlated with the degree of dimethylation due to the basal levels of ribosomal methylation that vary from strain to strain (13). More than 20 classes of erm genes have been identified. Some of these enzymes catalyze only monomethylation, some only dimethylation, whereas others catalyze either mono- or dimethylation. The erm genes may be found on high or low copy plasmid and within transposons, often in association with other antibiotic resistance genes (6). The pattern of each strain may depend not only on the erm determinant, but also on the structure of the attenuator controlling the gene expression that may differ in various class or subclass of erm genes (8). Furthermore, clinical strains may carry more than a single type of resistance $(1,6,8,13-14)$. All various aspects of macrolide-resistance lead to complex heterogeneous patterns characterized by different SXTROK interactions (synergism or indifference), thus making hard to correctly interpret in vitro results. Differences in the mechanism of cotrimoxazole resistance may only partially contribute to clear up the heterogeneous results observed among the iMLS $_{\text {в }}$ phenotype isolates. The overcoming of the 16-membered macrolide resistance may occur in presence of SXT in isolates with low basal methylation levels: this phenomenon may be due to the inhibition of the methyl group transferase activity by cotrimoxazole blocking folic acid synthesis, which is essential in the formation of S-adenosyl-methionine (SAM), interfering with the methylation based on SAM as methyl donor $(6,13)$.

Despite some limitations that are present in this study and the fact that in vitro synergistic activity may not predict in vivo efficacy, our results suggest that the combination of ROK plus SXT could be of potential interest in the oral therapy of Staphylococcus infections.

\section{REFERENCES}

1. Abu-Gharbieh E, Vasina V, Poluzzi E, De Ponti F. Antibacterial macrolides: a drug class with a complex pharmacological profile. Pharmacol Res 2004; 50: 211-22.

2. Brun-Pascaud M, Chau F, Derouin F, Girard PM. Experimental evaluation of roxithromycin combined with dapsone or sulphamethoxazole on Pneumocystis carinii and Toxoplasma gondii dual infections in a rat model. J Antimicrob Chemother 1998; 41 (Suppl B): S57-S62.

3. Clinical and Laboratory Standards Institute/NCCLS. Performance Standards for Antimicrobial susceptibility testing; sixteenth Informational Supplement. CLSI/NCCLS document M100-S16. Clinical and Laboratory Standards Institute, Wayne, Pennsylvania, 2006.

4. Gatermann SG, Koschinski T, Friedrich S. Distribution and expression of macrolide resistance genes in coagulase-negative staphylococci. Clin Microbiol Infect 2007; 13: $777-81$

5. Giovanetti E, Montanari MP, Mingoia M, Varaldo PE. Phenotypes and genotypes of erythromycin-resistant Streptococcus pyogenes strains in Italy and heterogeneity of inducibly resistant strains. Antimicrob Agents Chemother 1999; 43: 1935-40.

6. Katz L, Ashley GW. Translation and protein synthesis: macrolides. Chem Rev 2005; 105: 499-527.

7. Lapointe JR, Lavallee C, Meilleur R, Bourget C. Roxithromycin alone and in combination with sulphamethoxazole against Haemophilus influenzae. J Antimicrob Chemother 1987; 20 (Suppl B): S21-S9.

8. Leclercq R. Mechanisms of resistance to macrolides and lincosamides: nature of the resistance elements and their clinical implications. Clin Infect Dis 2002; 34: 482-92.

9. Lina G, Quaglia A, Reverdy ME, Vandenesch F, Etienne J. Distribution of genes encoding resistance to macrolides, lincosamides, and streptogramins among staphylococci. Antimicrob Agents Chemother 1999; 43: 1062-6.

10. Lorian V. Antibiotics in laboratory medicine $\left(5^{\text {th }} \mathrm{ed}\right.$.), LWW press, Philadelphia, PA, 2005.

11. Murray PR, Baron EJ, Pfaller MA, Tenover FC, Yolken RH. Manual of clinical microbiology ( $7^{\text {th }}$ ed.), ASM Press, Washington, DC, 1999.

12. National Committee for Clinical Laboratory Standards. Methods for determining bactericidal activity of antimicrobial agents. Approved guideline M26-A, vol. 19. National Committee for Clinical Laboratory Standards, Wayne, Pennsylvania, 1999.

13. Retsema J, Fu W. Macrolides: structures and microbial targets. Int J Antimicrob Agents 2001; 18: S3-S10.

14. Roberts MC, Sutcliffe J, Courvalin P, Jensen LB, Rood J, Seppala H. Nomenclature for macrolide and macrolidelincosamide-streptogramin B resistance determinants. Antimicrob Agents Chemother 1999; 43: 2823-30.

15. Roveta S, Marchese A, Debbia EA, Bandettini R. Sinergismo in vitro tra rokitamicina e cotrimossazolo in $S$. pyogenes e S. pneumoniae. Microb Med 2007; 22: 31-5.

16. Saiman L, Chen Y, Gabriel PS, Knirsch C. Synergistic activities of macrolide antibiotics against Pseudomonas aeruginosa, Burkholderia cepacia, Stenotrophomonas maltophilia, and Alcaligenes xylosoxidans isolated from patients with cystic fibrosis. Antimicrob Agents Chemother 2002; 46: 1105-7.

17. Schmitz FJ, Sadurski R, Kray A, et al. Prevalence of macrolide-resistance genes in Staphylococcus aureus and Enterococcus faecium isolates from 24 European university hospitals. Antimicrob Chemother 2000; 45: 891-4.

18. Seppälä H, Nissinen A, Yu Q, Huovinen P. Three different phenotypes of erythromycin-resistant Streptococcus pyogenes in Finland. J Antimicrob Chemother 1993; 32: 885-91.

19. Walsh C. Antibiotics: actions, origins, resistance. ASM Press, Washington DC, 2003. 